\title{
HUBUNGAN MANAJEMEN WAKTU BELAJAR DAN PERAN SERTA ORANGTUA TERHADAP PRESTASI BELAJAR MATEMATIKA SISWA KELAS XI IPA SMAN 5 BATAM
}

\author{
RELATIONSHIP OF TIME LEARNING AND ROLE MANAGEMENT AND PARENTS \\ TO MATHEMATICAL LEARNING ACHIEVEMENTS \\ STUDENTS OF SMAN 5 BATAM IPA XI CLASS
}

\author{
Mardeka Wati ${ }^{* 1}$, Nailul Himmi ${ }^{2}$ \\ Program Studi Pendidikan Matematika, Fakultas Keguruan dan Ilmu Pendidikan \\ Universitas Riau Kepulauan, Batam, Kepulauan Riau, Indonesia \\ ${ }^{* 1}$ mardekaaw@yahoo.com
}

\begin{abstract}
Abstrak
Penelitian ini untuk mengetahui: (1) Hubungan positif dan signifikan antara manajemen waktu belajar dengan prestasi belajar matematika siswa SMAN 5 Batam. (2) Hubungan positif dan signifikan antara peran serta orang tua dengan prestasi belajar matematika siswa SMAN 5 Batam. (3) Hubungan positif dan signifikan antara manajemen waktu belajar dan peran serta orang tua secara bersama-sama dengan prestasi belajar matematika siswa. Penelitian ini merupakan penelitian korelasional. Populasi dalam penelitian ini adalah siswa kelas XI IPA SMAN 5 Batam Tahun Pelajaran 2017/2018 sejumlah 217 siswa dengan jumlah sampel 141 siswa. Instrument penelitian menggunakan angket sudah dianalisis validasi dan reliabilitas. Pengambilan sampel dilakukan dengan teknik Simple Random Sampling. Pengujian hipotesis dengan menggunakan analisis korelasi Pearson Product Moment dan analisis korelasi ganda, yang sebelumnya dilakukan uji prasyarat analisis meliputi uji normalitas. Hasil penelitian menunjukkan bahwa: (1) Terdapat hubungan positif dan signifikan antara manajemen waktu belajar dengan prestasi belajar matematika siswa dengan $r_{\text {hitung }}=0.517$ pada kategori cukup kuat, (2) Terdapat hubungan positif dan signifikan peran serta orang tua dengan prestasi belajar matematika siswa dengan $r_{\text {hitung }}=0.207$ pada kategori rendah, (3) Terdapat hubungan positif dan signifikan antara manajemen waktu belajar dan peran serta orang tua secara bersama-sama dengan prestasi belajar matematika siswa dengan $R_{\text {hitung }}=0.205$ pada kategori rendah.
\end{abstract}

Kata Kunci: Manajemen Waktu Belajar, Peran Serta Orang Tua, dan Prestasi Belajar Matematika

\begin{abstract}
This research aims to find out: (1) The positive and significant relationship between learning time management and mathematic learning achievement of students in SMAN 5 Batam. (2) The positive and significant relationship between parent's participation and mathematic learning achievement of students in SMAN 5 Batam for academic year 2017/2018. (3) The positive and significant relationship between learning time management and parent's participation with mathematic learning achievement of students in SMAN 5 Batam for academic year 2017/2018. This research is a correlational research. Population in this research is student of class XI IPA SMAN 5 Batam consist of 217 student with sample consist of 141 student. Instrument research using questionnaire already analyzed validation and reliability. Technical sampling use Simple Random Sampling. To testing hypothesis use correlation analysis Pearson Product Moment and multiple correlation analysis, previously tested requirement analysis include test of normaliyt. Base on research: (1) There is positive and significant relationship between time management and mathematic learning achievement of students with $r_{\text {hitung }}=0.517$ on category quite strong, (2) there is positive and significant relationship between parent's participation and mathematic learning achievement of students with $r_{\text {hitung }}=0.207$ on category low, (3) There is positive and significant relationship between learning time management and parent's participation with mathematic learning achievement of students with $R_{\text {hitung }}=0.205$ on category low.
\end{abstract}

\section{KeyWords: Learning Time Management, Parent's Participation, and Mathematic Learning Achievement}




\section{PENDAHULUAN}

Perkembangan ilmu pengetahuan erat kaitannya dengan perkembangan pendidikan, dimana pendidikan mempunyai peran yang penting di zaman seperti saat ini, karena melalui pendidikanlah seseorang dapat memperoleh ilmu pengetahuan. Mengingat isi pembukaan UUD 1945 alenia IV yang menegaskan bahwa salah satu tujuan nasional bangsa Indonesia adalah mencerdaskan kehidupan bangsa. Salah satu cara mencerdaskan kehidupan bangsa yaitu dengan meningkatkan mutu pendidikan. Terkait dengan dunia pendidikan, untuk menciptakan manusia yang berkualitas dan berprestasi tinggi tinggi tentunya setiap siswa harus memiliki prestasi belajar yang baik. Prestasi belajar siswa merupakan tolak ukur keberhasilan belajar siswa yang dapat dilihat dari penguasaan siswa akan beberapa mata pelajaran yang ditempuhnya. Untuk mewujudkan keberhasilan belajar dibutuhkan kerjasama antara siswa, guru, dan orangtua.

Salah satu indikator yang penting untuk mengukur keberhasilan pendidikan dapat dilihat dari prestasi belajar siswa yang dapat ditunjukan melalui nilai yang diberikan oleh seorang guru dari berbagai mata pelajaran yang telah dipelajari siswa. "Prestasi belajar dikatakan tinggi apabila sudah dapat melampaui batas kriteria ketuntasan minimal (KKM), dapat pula dilihat dari prestasi ujian yang didapat siswa dan sebaliknya, prestasi belajar matematika dikatakan rendah apabila belum mencapai batas kriteria ketuntasan minimal (KKM)" Hasbullah (2013: 2). Prestasi belajar sangat erat kaitannya dengan kualitas siswa itu sendiri, guru, dan orangtua dalam mendukung kegiatan pembelajaran. Salah satu keberhasilan kegiatan belajar mengajar dapat dilihat dari prestasi belajar siswa yang diperoleh setelah proses pembelajaran. Namun, tidak semua siswa dapat mencapai prestasi belajar sesuai yang diharapkan. Hal ini terlihat dari rendahnya prestasi belajar matematika siswa di SMAN 5 Batam yang di lihat dari nilai UAS Semester Ganjil Tahun Pelajaran 2017/2018.

Tabel 1 Persentase nilai UAS SMAN 5 Batam

\begin{tabular}{|c|c|c|c|c|c|c|}
\hline \multirow[b]{2}{*}{ No } & \multirow[b]{2}{*}{ KELAS } & \multirow[b]{2}{*}{ KKM } & \multicolumn{2}{|c|}{ Jumlah siswa } & \multicolumn{2}{|c|}{ PERSENTASE } \\
\hline & & & TUNTAS & $\begin{array}{c}\text { TIDAK } \\
\text { TUNTAS }\end{array}$ & TUNTAS & $\begin{array}{c}\text { TIDAK } \\
\text { TUNTAS }\end{array}$ \\
\hline $\mathbf{1}$ & XI IPA 1 & \multirow{6}{*}{73} & 20 & 25 & $44,5 \%$ & $55,5 \%$ \\
\hline 2 & XI IPA 2 & & 22 & 20 & $52 \%$ & $48 \%$ \\
\hline 3 & XI IPA 3 & & 14 & 28 & $33 \%$ & $67 \%$ \\
\hline 4 & XI IPA 4 & & 15 & 29 & $34 \%$ & $66 \%$ \\
\hline 5 & XI IPA 5 & & 12 & 32 & $27 \%$ & $73 \%$ \\
\hline & JMLAH & & 83 & 134 & $38 \%$ & $62 \%$ \\
\hline
\end{tabular}


Berdasarkan tabel 1 di atas, dapat terlihat bahwa prestasi belajar matematika siswa belum optimal karena persentase ketidaktuntasan terbilang tinggi dan sebaliknya untuk ketuntasan. Berhasil atau tidaknya suatu proses belajar mengajar pendidikan tergantung dari faktor-faktor dan kondisi yang mempengaruhi proses belajar mengajar tersebut. Menurut Slameto (dalam Juliasari \& Benedictus, 2016:406) Faktor yang mempengaruhi belajar dikelompokkan menjadi dua, yaitu faktor intern dan faktor ekstern. Faktor intern berasal dari dalam diri individu yang sedang belajar sedangkan faktor ekstern yang berasal dari luar individu yang sedang belajar antara lain manajemen waktu belajar. Faktor ekstern diantaranya faktor yang berasal dari keluarga (peran serta orang tua), sekolah, dan lingkungan sekitar. "Manajemen waktu adalah kemampuan untuk memutuskan apa yang paling penting dalam kehidupan baik di tempat kerja (dalam hal ini di sekolah), di rumah, dan bahkan dalam kehidupan pribadi” Linda (2017: 2). Terry (dalam Rusdi, 2015:57) mengatakan bahwa perlu adanya manajemen yang berfungsi sebagai perencanaan, penggerak, pengendalian atau pengawasan dan pengorganisasian.

Berdasarkan wawancara peneliti pada tanggal 8 Januari 2018 bersama siswa dari kelas XI. Subjek 1 mengatakan bahwa mengerjakan tugas jika hendak dikumpul saja, dikerjakan sendiri dan terkadang menyalin tugas teman yang sudah selesai di sekolah. Subjek 2 mengatakan tugas akan dikerjakan jika sudah mendekati waktu deadline saja dan terkadang mengerjakan di sekolah karena lelah jika harus menambah waktu belajar dirumah. Sedangkan Subjek 3 mengatakan mengerjakan tugas ketika pulang sekolah atau mengerjakan di tempat bimbingan belajar (les).

Berdasarkan observasi peneliti di kelas XI IPA SMAN 5 Batam pada tanggal 8 Januari 2018, masih terdapat siswa yang belum menggunakan waktunya secara baik dalam hal kedisiplinan. Antara lain bila bel masuk berbunyi siswa tidak langsung masuk ke kelas sehingga jam belajar terbuang, siswa terkadang keluar kelas pada jam pelajaran dengan alasan ke toilet untuk cuci muka bahkan ada yang ke kantin, pada jam pelajaran siswa tidak memperhatikan guru mengajar dan tidak dapat memahami materi yang disampaikan. Masih lalainya siswa dalam mengerjakan latihan yang diberikan oleh guru, sehingga siswa hanya mencontek dan bergantung pada pekerjaan temannya yang lain.

Selain manajemen waktu belajar, peran serta orang tua juga menjadi faktor yang mendukung keberhasilan prestasi belajar yang baik. Pendidikan dikeluarga sangat penting jika dibandingkan pendidikan sekolah dan pendidikan di masyarakat. Pendidikan di keluarga 
adalah yang utama sebab di keluarga anak lahir dan dibesarkan. Di keluarga anak belajar berbicara, berjalan, makan makanan yang sehat, mengenal ibu dan ayahnya yang secara sosisal mengenal perilaku manusia dan lingkungannya (Willis, 2012:127). Peran orang tua dalam mendukung siswa dalam belajar juga merupakan faktor yang mempengaruhi prestasi belajar siwa. Orang tua seharusnya sebagai orang pertama yang meletakkan dasar-dasar pendidikan terhadap anak-anaknya, karena lingkungan keluarga terutama orang tua merupakan lingkungan pendidikan pertama yang mempunyai peranan penting dalam menentukan dan membina proses perkembangan anak. Tidak menutup kemungkinan bahwa masalah yang dialami siswa di sekolah seperti rendahnya prestasi belajar siswa dan berhasil tidaknya proses belajar siswa merupakan akibat atau lanjutan dari situasi dimana kurangnya perhatian orang tua, lingkungan keluarga yang tidak harmonis dan peran orang tua yang tidak dijalankan dengan baik.

Perhatian orang tua terhadap pendidikan anak dalam rumah tangga sangat menentukan keberhasilan anak dalam belajar, hal ini memberikan dampak positif terhadap perubahan tingkah laku dan perkembangan pendidikan anak. Orang tua memperhatikan cara belajar anak di rumah sehingga anak memperoleh prestasi belajar yang baik di sekolah. Peran serta orang tua menurut Anggraeni et al (2015: 14) merupakan keterlibatan yang nyata dalam suatu sistem pendidikan yaitu bisa berupa gagasan, kritik membangun, dukungan, dan pelaksanaan pendidikan. Kesulitan belajar yang dialami oleh siswa tidak terlepas dari peranan orang tua dalam memberikan bimbingan di rumah, memperhatikan anak dalam mengerjakan tugas, mengatur waktu belajar, bermain, dan waktu istirahat anak. Slameto (2010:60) mengemukakan cara orang tua mendidik anak besar pengaruhnya terhadap belajar anaknya, sehingga hasil belajar anak dipengaruhi oleh cara orang tua mendidik. "Orang tua merupakan penanggung jawab utama dalam pendidikan anak-anaknya, baik di lembaga formal maupun non formal orang tua tetap berperan dalam menentukan masa depan pendidikan anakanaknya" Umar (2015:1).

Berdasarkan hasil wawancara langsung dengan 5 orang tua dari siswa SMAN 5 Batam di dapatkan 3 di antaranya kurang memperhatikan kegiatan belajar anak karena sibuk dengan pekerjaan dan mempercayakan pendidikan anak pada lingkungan sekolah dan 2 di antaranya mengatakan mereka selalu memperhatikan dan memantau pendidikan anaknya baik dirumah maupun di sekolah. Dari hasil wawancara juga dari beberapa siswa di dapatkan sebagian besar dari mereka jika berkomunikasi dengan orang tua tidak menanyakan tentang sekolah, 
orang tua jarang menanyakan tentang tugas sekolah, dan jarang menemani mereka saat belajar dirumah.

\section{METODOLOGI}

Jenis penelitian yang digunakan dalam penelitian ini adalah penelitian kuantitatif. Metode penelitian menggunakan penelitian korelasional. "Populasi adalah wilayah generalisasi yang terdiri atas: obyek/subyek yang mempunyai kualitas dan karakteristik tertentu yang ditetapkan oleh peneliti untuk dipelajari dan kemudian ditarik kesimpulannya" (Sugiyono, 2011: 80). Populasi dalam penelitian ini adalah siswa kelas XI IPA SMAN 5 Batam Tahun Pelajaran 2017/2018 sejumlah 217 siswa. Pengambilan sampel dilakukan dengan teknik Simple Random Sampling. Riduwan (2012: 58) mengatakan simple random sampling adalah cara pengambilan sampel dari anggota populasi dengan menggunakan acak tanpa memperhatikan strata (tingkatan) dalam anggota populasi. Untuk menentukan jumlah sampel peneliti menggunakan rumus dari Taro Yamane maka didapatkan sampel dalam penelitian ini berjumlah 141 siswa. Pada penelitian ini terdapat dua variabel yaitu variabel: independen (variabel bebas) dan variabel dependen (variabel terikat). Yaitu variabel bebas adalah Manajemen Waktu Belajar $\left(\mathrm{X}_{1}\right)$, dan Peran serta Orang Tua $\left(\mathrm{X}_{2}\right)$. Serta variabel terikat adalah Prestasi Belajar Siswa (Y). Instrumen yang peneliti gunakan dalam penelitian ini adalah kuesioner atau angket.

Instrument penelitian menggunakan angket sudah dianalisis validasi dan reliabilitas. Pengambilan sampel dilakukan dengan teknik Simple Random Sampling. Pengujian hipotesis dengan menggunakan analisis korelasi Pearson Product Moment dan analisis korelasi ganda, yang sebelumnya dilakukan uji prasyarat analisis meliputi uji normalitas.

\section{Hasil Penelitian dan Pembahasan}

Sebelum dilakukan uji hipotesis terlebih dahulu dilakukan uji prasyarat hipotesis yaitu ui normalitas. Berdasarkan perhitungan uji normalitas menggunakan Software SPSS 20. Dengan kriteria keputusan, jika nilai sig > 0.05 maka data berdistribusi normal, namun jika sig $\leq 0.05$ maka data tidak berdistribusi normal. 


\section{Tabel 2 Hasil Uji Normalitas}

Tests of Normality

\begin{tabular}{|ll|r|r|r|}
\hline & & \multicolumn{3}{|c|}{ Kolmogorov-Smirnov $^{\mathrm{a}}$} \\
\cline { 3 - 5 } & & \multicolumn{1}{|c|}{ Statistic } & \multicolumn{1}{c|}{ df } & \multicolumn{1}{c|}{ Sig. } \\
\hline \multirow{2}{*}{ DATA } & MANAJEMEN WAKTU BELAJAR & .065 & 141 & .200 \\
& PERAN SERTA ORANG TUA & .073 & 141 & .065 \\
& PRESTASI BELAJAR MATEMATIKA & .069 & 141 & .094 \\
\hline
\end{tabular}

*. This is a lower bound of the true significance.

a. Lilliefors Significance Correction

Berdasarkan output di atas dapat dilihat nilai sig. variabel manajemen waktu belajar, variabel peran serta orang tua dan variabel prestasi belajar matematika $>0.05$. Karena semua variabel memiliki nilai sig. $>0.05$ artinya semua data berdistribusi normal.

Hasil pengujian hipotesis pertama menunjukkan bahwa terdapat hubungan yang positif dan signifikan antara manajemen waktu belajar dengan prestasi belajar matematika siswa. Hal ini ditunjukkan dengan koefisien korelasi sebesar 0.517 yang dikonsultasikan dengan ketentuan taraf signifikansi $5 \%, d k=n-2=141-2=139$ sehingga di dapatkan $\mathrm{t}_{\text {tabel }}=1.655$. Dimana dalam hasil perhitungan diperoleh $\mathrm{t}_{\text {hitung }}=8.326$ dan $\mathrm{t}_{\text {tabel }}=1.655$ dimana $t_{\text {hitung }}(8.326)>t_{\text {tabel }}(1.655)$. Sedangkan besar sumbangan manajemen waktu belajar terhadap prestasi belajar matematika sebesar 26.73\%. Hal ini menunjukkan siswa sudah bisa mengalokasikan waktunya dengan baik, efektif dan efisien untuk belajar, membagi waktu dan melaksanakan jadwal yang telah dibuat sehingga siswa mampu menetapkan tujuan dan prioritasnya yaitu meningkatkan prestasi belajar. Sebaliknya jika siswa kurang memperhatikan manajemen waktu belajar maka akan kesulitan mencapai tujuan dan prioritasnya. Artinya semakin baik manajemen waktu belajar siswa maka akan semakin tinggi pula prestasi belajar matematika siswa dan sebaliknya. Dari hasil penelitian di atas maka disimpulkan bahwa manajemen waktu belajar siswa memiliki hubungan hubungan positif dan signifikan terhadap prestasi belajar matematika siswa. Pernyataan ini diperkuat oleh penelitian sebelumnya oleh Nurita Juliasari dan Benedictus Kusmanto (2016) yang mengemukakan bahwa ada hubungan yang positif dan signifikan antara manajemen waktu belajar, motivasi belajar, dan fasilitas belajar dengan prestasi belajar matematika siswa SMP kelas VIII se-kecamatan Danurejan Yogyakarta.

Hasil pengujian hipotesis kedua menunjukkan bahwa terdapat hubungan yang positif dan signifikan antara peran serta orang tua dengan prestasi belajar matematika siswa. Hal ini ditunjukkan dengan koefisien korelasi sebesr 0.207 dikonsultasikan dengan dengan ketentuan taraf signifikansi $5 \%, d k=n-2=141-2=139$ sehingga di dapatkan $t_{\text {tabel }}=1.655$. 
Dimana dalam hasil perhitungan diperoleh $t_{\text {hitung }}=2.452$ dan $t_{\text {tabel }} 1.655$ dimana $t_{\text {hitung }}(2.452)$ $>t_{\text {tabel }}$ (1.655). Sedangkan harga koefisien determinasi sebesar $4.285 \%$. Hal ini menunjukkan orang tua mempunyai peran agar tetap terlibat dalam mendukung proses belajar anak. Cara orang tua untuk tetap terlibat dalam proses belajar anak diantaranya yaitu memberi perhatian, mengontrol waktu dan efektifitas belajar anak dan membentuk sikap dan pola perilaku yang diharapkan sehingga dapat meningkatkan prestasi belajar matematika siswa. Dari hasil penelitian ini didapatkan bahwa peran serta orang tua memiliki hubungan positif dan signifikan terhadap prestasi belajar matematika siswa dalam kategori rendah, namun tidak dapat dipungkiri bahwa peran serta orang tua tetap berpengaruh terhadap prestasi belajar siswa walaupun sedikit. Pernyataan ini diperkuat oleh penelitian sebelumnya oleh Henry Paladeng (2015) yang mengemukakan bahwa ada hubungan peran orang tua dengan prestasi belajar anak usia sekolah di SDN Inpres I Tumaratas. Adapun pernyataan lain yang di kemukakan oleh Jannah (2015) bahwa ada pengaruh yang signifikan peran orang tua terhadap prestasi belajar siswa di MA Mirqatul Ulum Liprak Kulon Banyuanyar Probolinggo.

Hasil pengujian hipotesis ketiga menunjukkan bahwa terdapat hubungan yang positif dan signifikan antara manajemen waktu belajar dan peran serta orang tua secara bersamasama dengan prestasi belajar matematika siswa. Hal ini ditunjukkan dengan koefisien korelasi $\mathrm{X}_{1} \mathrm{X}_{2} \mathrm{Y}$ sebesar 0.205 terletak pada kategori rendah berdasarkan tabel 8. Dimana $\mathrm{F}_{\text {hitung }}$ (3.090) $>F_{\text {tabel }}$ (3.060). Sedangkan harga koefisien determinasi sebesar $4.21 \%$. Adapun analisis data hasil penelitian peneliti menggunakan analisis persentase ketercapaian secara klasikal skor untuk indikator sebagai berikut :

1. Indikator Manajemen Waktu Belajar

Tabel 3 Indikator Manajemen Waktu Belajar

\begin{tabular}{|c|c|c|c|c|}
\hline Variabel & Indikator & Jumlah & $\begin{array}{c}\text { Persenta } \\
\text { se }\end{array}$ & Kategori \\
\hline \multirow{4}{*}{$\begin{array}{l}\text { Manajeme } \\
\text { n Waktu } \\
\text { Belajar }\end{array}$} & $\begin{array}{c}\text { Mengatur waktu } \\
\text { dengan teratur }\end{array}$ & $\begin{array}{c}2,12,16,17 \\
18,19\end{array}$ & $70.6 \%$ & Baik \\
\hline & $\begin{array}{c}\text { Menyelesaikan tugas } \\
\text { tepat waktu }\end{array}$ & $9,10,21,22,23$ & $71.9 \%$ & Baik \\
\hline & $\begin{array}{c}\text { Merencanakan } \\
\text { jadwal dengan baik }\end{array}$ & $4,5,6,7,8,20$ & $67.3 \%$ & Baik \\
\hline & $\begin{array}{c}\text { Menggunakan waktu } \\
\text { secara efektif dan } \\
\text { efisien }\end{array}$ & $\begin{array}{c}1,3,11,13,14 \\
15,24\end{array}$ & $69.7 \%$ & Baik \\
\hline \multicolumn{2}{|r|}{ Jumlah } & 24 & & \\
\hline
\end{tabular}


2. Indikator Peran Serta Orang Tua

Tabel 4 Indikator Peran Serta Orang Tua

\begin{tabular}{|c|c|c|c|c|}
\hline Variabel & Indikator & Jumlah & Persentase & Kategori \\
\hline \multirow{4}{*}{$\begin{array}{c}\text { Peran } \\
\text { serta } \\
\text { orang tua }\end{array}$} & $\begin{array}{c}\text { Mengontrol waktu } \\
\text { belajar dan cara } \\
\text { belajar anak }\end{array}$ & $\begin{array}{c}1,3,7,8,10 \\
11,16,19,21\end{array}$ & $71,9 \%$ & Baik \\
\hline & $\begin{array}{c}\text { Memantau } \\
\text { perkembangan } \\
\text { kemampuan } \\
\text { akademik anak }\end{array}$ & $\begin{array}{c}9,14 \\
15\end{array}$ & $75 \%$ & $\begin{array}{c}\text { Sangat } \\
\text { Baik }\end{array}$ \\
\hline & $\begin{array}{c}\text { Memantau } \\
\text { perkembangan } \\
\text { kepribadian }\end{array}$ & $2,5,17,18$ & $81.3 \%$ & $\begin{array}{c}\text { Sangat } \\
\text { Baik }\end{array}$ \\
\hline & $\begin{array}{c}\text { Memantau } \\
\text { efektifitas jam } \\
\text { belajar di sekolah. }\end{array}$ & $4,6,12,13,20$ & $74.8 \%$ & Baik \\
\hline \multicolumn{2}{|r|}{ Jumlah } & 21 & & \\
\hline
\end{tabular}

Jika dilihat dari persentase ketercapaian per indikator berada pada kategori baik sehingga dapat disimpulkan bahwa siswa telah memiliki ketercapaian manajemen waktu belajar dan peran serta orang tua yang cukup baik. Sehingga manajemen waktu belajar dan peran serta orang tua secara bersama-sama memiliki hubungan positif terhadap prestasi belajar matematika siswa berarti semakin tinggi manajemen waktu belajar siswa dan peran serta orang tua secara bersama-sama maka akan semakin tinggi pula prestasi belajar matematika siswa dan sebaliknya semakin rendah manajemen waktu belajar siswa dan peran serta orang tua secara bersamasama maka akan semakin rendah pula prestasi belajar matematika siswa tersebut. Dari hasil penelitian di atas maka disimpulkan bahwa manajemen waktu belajar dan peran serta orang tua secara bersama-sama memiliki hubungan positif terhadap prestasi belajar matematika siswa. Pernyataan ini diperkuat oleh penelitian sebelumnya oleh Mulyadi (2015) yang mengemukakan bahwa terdapat hubungan positif dan signifikan antara perhatian orangtua dan manajemen waktu belajar di rumah secara bersamasama dengan prestasi belajar geografi siswa, semakin tinggi perhatian orangtua dan manajemen waktu belajar di rumah maka semakin tinggi pula prestasi belajar yang dicapai siswa. 


\section{KESIMPULAN DAN SARAN}

\section{Kesimpulan}

Berdasarkan penelitian dan pembahasan yang telah dilakukan, diperoleh kesimpulan, yaitu:

1. Terdapat hubungan yang positif dan signifikan antara manajemen waktu belajar siswa dengan prestasi belajar matematika siswa yang ditunjukkan dengan koefisien korelasi 0,517 dan besarnya kontribusi manajemen waktu belajar siswa dengan prestasi belajar matematika siswa $26,73 \%$.

2. Terdapat hubungan yang positif dan signifikan antara peran serta orang tua dengan prestasi belajar matematika siswa yang ditunjukkan dengan koefisien korelasi 0,207 dan besarnya kontribusi peran serta orang tua dengan prestasi belajar matematika siswa 4,285\%.

3. Terdapat hubungan yang positif dan signifikan antara manajemen waktu belajar siswa dan peran serta orang tua secara bersama-sama dengan prestasi belajar matematika siswa yang ditunjukkan dengan koefisien korelasi ganda 0,205 dan besarnya kontribusi manajemen waktu belajar siswa dan peran serta orang tua secara bersama-sama dengan prestasi belajar matematika siswa 4,21\%.

\section{REFERENSI}

Anggraeni.N.D, Yoto, \& Basuki. (2015). Studi tentang peran serta orang tua dan dunia usaha/industry dalam peningkatan mutu pendidikan di SMK N 1 Singosari. Jurnal Teknik Mesin 23 (1). 11-20.

Hasbullah. (2013). Pengaruh komunikasi keluarga terhadap prestasi belajar matematika. Jurnal EducatiO 8(2). 1-15.

Juliasari, N. \& Benecdictus. (2016). Hubungan antara manajemen waktu belajar, motivasi belajar, dan fasilitas belajar dengan prestasi belajar matematika siswa SMP kelas VII se-Kecamatan Danurajen Yogyakarta. Jurnal Pendidikan Matematika 4 (3). 405-412.

Linda. (2017). Pengantar rancangan modul pelatihan manajemen waktu pada himpunan mahasiswa program studi psikologi Universitas "X". Jurnal Psikologi Psibernetika 10 (1). 1-8.

Riduwan. (2012). Belajar mudah penelitian untuk guru - karyawan dan peneliti pemula. Bandung: Alfabeta. 
Rusdi, R. (2015). Hubungan antara efikasi diri dan manajemen waktu terhadap stress mahasiswa farmasi semester IV Universitas Mulawarman. eJournal Psikologi ISSN:0000-0000. 53-64.

Slameto. (2010). Balajar \& factor-faktor yang mempengaruhinya. Jakarta: Rineka Cipta.

Sugiyono. (2011). Metode penelitian kuantitatif, kualitatif, dan $r \& d$. Bandung: Alfabeta.

Umar, M. (2015). Peran orang tua dalam peningkatan prestasi belajar anak. Jurnal Ilmiah Edukasi 1 (1). 20-28.

Willis, SS. (2012). Psikologi pendidikan. Bandung: Alfabeta. 